\title{
Editorial
}

\section{A New MDPI Proceedings Journal: Biology and Life Sciences Forum}

\section{Ioana Craciun}

Citation: Craciun, I. A New MDPI Proceedings Journal: Biology and Life Sciences Forum. Biol. Life Sci. Forum 2021, 1, 1. https://doi.org/10.3390/ blsf2021001001

Received: 11 June 2021

Accepted: 11 June 2021

Published: 22 June 2021

Publisher's Note: MDPI stays neutral with regard to jurisdictional claims in published maps and institutional affiliations.

Copyright: (C) 2021 by the author Licensee MDPI, Basel, Switzerland. This article is an open access article distributed under the terms and conditions of the Creative Commons Attribution (CC BY) license (https:// creativecommons.org/licenses/by/ $4.0 /)$.
MDPI AG, St. Alban-Anlage 66, 4052 Basel, Switzerland; ioana.craciun@mdpi.com

Since the launch of its very first journal, MDPI has had a vested interest in open access scientific communication in all of its forms. Going beyond open access publications, MDPI launched Sciforum [1] in 2009 as a platform for scholarly exchange, discussion of novel research topics and establishing collaborations. To further enable the communication of results worldwide, we have launched the journal Proceedings, together with a series of proceeding journals [2] dedicated to communicating the scientific results and discussions arising from conferences, as well as workshops and other academic meetings. To expand and complement our series of proceedings journals, we are thrilled to announce the launch of the new journal Biology and Life Sciences Forum (ISSN 2673-9976) [3].

Biology and Life Sciences Forum is a journal that publishes proceedings resulting from academic conferences in all areas of biology and life sciences. We also welcome submissions from multidisciplinary conferences that focus on research at the interface of related disciplines. As this field rapidly evolves, it is important to establish a stage where industry and academia can come together and exchange ideas to advance the translation of research into practice.

We welcome all conference and event organizers to submit their proposals for publishing their conference proceedings to the Biology and Life Sciences Forum editorial office, and look forward to a fruitful collaboration with the Biology and Life Sciences community.

Conflicts of Interest: The author declares no conflict of interest.

\section{References}

1. Sciforum Home Page. Available online: https://sciforum.net/ (accessed on 9 June 2021).

2. MDPI Proceedings Journals Home Page. Available online: https://www.mdpi.com/about/ proceedings (accessed on 9 June 2021).

3. Biology and Life Sciences Forum Home Page. Available online: https://www.mdpi.com/journal/ blsf (accessed on 9 June 2021). 